\title{
Exocytosis of Neutrophil Granule Subsets and Activation of Prolyl Isomerase 1 Are Required for Respiratory Burst Priming
}

\author{
Kenneth R. McLeish ${ }^{\mathrm{a}, \mathrm{b}}$ Silvia M. Uriarte ${ }^{\mathrm{a}}$ Shweta Tandon ${ }^{\mathrm{a}} \quad$ Timothy M. Creed $^{\mathrm{a}}$ \\ Junyi Le ${ }^{\text {a }}$ Richard A. Ward ${ }^{\text {a }}$ \\ a Department of Medicine, University of Louisville, and ${ }^{b}$ Robley Rex VA Medical Center, Louisville, Ky., USA
}

\author{
Key Words \\ Exocytosis · MAPK - NADPH oxidase - Neutrophils · p38 . \\ Pin $1 \cdot$ Priming
}

\begin{abstract}
This study tested the hypothesis that priming the neutrophil respiratory burst requires both granule exocytosis and activation of the prolyl isomerase Pin 1. Fusion proteins containing the TAT cell permeability sequence and either the SNARE domain of syntaxin-4 or the N-terminal SNARE domain of SNAP-23 were used to examine the role of granule subsets in TNF-mediated respiratory burst priming using human neutrophils. Concentration-inhibition curves for exocytosis of individual granule subsets and for priming of fMLF-stimulated superoxide release and phagocytosis-stimulated $\mathrm{H}_{2} \mathrm{O}_{2}$ production were generated. Maximal inhibition of priming ranged from 72 to $88 \%$. Linear regression lines for inhibition of priming versus inhibition of exocytosis did not differ from the line of identity for secretory vesicles and gelatinase granules, while the slopes or the $y$-intercepts were different from the line of identity for specific and azurophilic granules. Inhibition of Pin 1 reduced priming by $56 \%$, while exocytosis of secretory vesicles and specific granules was not affected. These findings indicate that exocytosis of secretory vesicles and gelatinase granules and activation of Pin 1 are independent events required for TNF-mediated priming of neutrophil respiratory burst.

Copyright $\odot 2013$ S. Karger AG, Basel
\end{abstract}

\section{Introduction}

The response of neutrophils to a stimulus is not static but shows transitions through several states, referred to as resting, primed, and activated. Typically, these states are defined by the level of reactive oxygen species (ROS) generation by the respiratory burst. Circulating blood neutrophils are normally in the resting state, characterized by little or no basal respiratory burst activity and a very low capacity to respond to activation signals. Primed neutrophils also show low basal respiratory burst activity, but they undergo a rapid and robust respiratory burst in response to activation signals, such as receptor-mediated phagocytosis or interaction of formylated peptides or the complement component $\mathrm{C} 5 \mathrm{a}$ with specific cell surface receptors. The respiratory burst can be primed by neutrophil adhesion, pro-inflammatory cytokines, bacterial and viral products, and pro-inflammatory lipids $[1,2]$.

The respiratory burst is generated by the NADPH oxidase, a multi-component enzyme with membrane and cytosolic components $[3,4]$. In neutrophils, the membrane components are gp $91^{\text {phox }}$ and $\mathrm{p} 22^{\text {phox }}$, which form the heterodimeric cytochrome $b_{558}$. The cytosolic components are $\mathrm{p} 47^{\text {phox }}, \mathrm{p} 67^{\text {phox }}, \mathrm{p} 40^{\text {phox }}$, and a GTPase, Rac2. Activation of the oxidase requires the cytosolic components to translocate to a membrane and interact with cytochrome $b_{558}$. In resting neutrophils, the majority of cytochrome $\mathrm{b}_{558}$ is located in the membranes of specific granules, ge-

\section{KARGER}

Fax +4161306 1234

E-Mail karger@karger.ch

www.karger.com
(C) 2013 S. Karger AG, Basel

$1662-811 X / 13 / 0053-0277 \$ 38.00 / 0$

Accessible online at:

www.karger.com/jin
Dr. Kenneth R. McLeish

Baxter I Research Building, 102F, University of Louisville

570 S. Preston Street

Louisville, KY 40202 (USA)

E-Mail k.mcleish@louisville.edu 
latinase granules, and secretory vesicles [5-7]. When neutrophils undergo exocytosis, fusion of granules with the plasma membrane increases the expression of cytochrome $\mathrm{b}_{558}$, potentially providing additional docking sites for $\mathrm{cy}$ tosolic NADPH oxidase components that translocate to the plasma membrane upon activation [8-10]. We recently reported that selective inhibition of exocytosis blocked neutrophil priming by TNF and PAF [10]. Those results support the hypothesis that cytochrome $b_{558}$ redistribution during exocytosis is a mechanism by which NADPH oxidase activation is enhanced during priming.

Substantial evidence indicates that phosphorylation of cytosolic components of the NADPH oxidase also participates in priming. Two priming agents, GM-CSF and TNF, were shown to induce phosphorylation of $\mathrm{p} 47^{\text {phox }}$ on $\mathrm{Ser}^{345}$, and that phosphorylation was necessary for neutrophil priming [11]. Boussetta et al. [12] recently reported that TNF-induced $\mathrm{p} 38$ MAPK phosphorylation of p4 $7^{\text {phox }}$ on Ser ${ }^{345}$ generated a binding domain for the prolyl isomerase Pin1, and TNF also stimulated activation of Pin1. Binding of activated Pin1 to $\mathrm{p} 47^{\text {phox }}$ induced a conformational change that exposed sites for PKC phosphorylation. The authors proposed that the enhanced phosphorylation by PKC induced enhanced translocation of p $47^{\text {phox }}$ to the plasma membrane, leading to increased ROS generation.

As inhibition of exocytosis and inhibition of Pin 1 activity each blocked neutrophil priming $[10,12]$, the relative contributions of exocytosis and enhanced translocation of cytosolic components to priming are unclear. In the present study, we compared the ability of two TAT fusion proteins containing the SNARE domain of SNAP23 (TAT-SNAP-23) or syntaxin 4 (TAT-syntaxin-4) to inhibit exocytosis of each neutrophil granule subset and to inhibit priming. Additionally, the effect of Pin1 inhibition on priming and granule exocytosis was compared. Our results suggest that both exocytosis of secretory vesicles and gelatinase granules and Pin1 activity are necessary for neutrophil priming. We suggest that these represent parallel pathways that must both be initiated for priming to occur.

\section{Materials and Methods}

\section{Materials}

Recombinant human TNF was from R\&D Systems (Minneapolis, Minn., USA). Latrunculin A, fMLF, and protease and phosphatase inhibitors were from Sigma-Aldrich (St. Louis, Mo., USA). SB203580, MAPKAPK-2 inhibitor III, and the Pin1 inhibitor, juglone, were from Calbiochem (San Diego, Calif., USA). Rabbit an- ti-p47 ${ }^{\text {phox }}$ was a generous gift from Dr. William M. Nauseef (University of Iowa, Iowa City, Iowa, USA).

\section{Neutrophil Isolation}

Neutrophils were isolated from the blood of healthy donors using plasma-Percoll gradients as previously described $[13,14]$. Microscopic evaluation of isolated cells showed that $>92 \%$ of cells were neutrophils. Trypan blue exclusion indicated that $>95 \%$ of cells were viable. The Institutional Review Board of the University of Louisville approved the use of human donors who provided informed consent.

\section{TAT Fusion Proteins}

TAT-SNAP-23 and TAT-control were prepared as described previously [10]. To generate TAT-syntaxin-4, a forward primer (5'-GATCCATGGTGACTCGACAGGCCTTAAA-3') containing a Ncol restriction site and a reverse primer ( $5^{\prime}$-ATGGAATTCTCAGGCCGTCTTGACGTGCTCCT-3') containing an EcoR1 restriction site were designed to generate the cDNA sequence for the SNARE domain of syntaxin-4 (amino acid 195-262) from cDNA generated from human neutrophil RNA. Following verification of the PCR product by DNA sequencing, the PCR product and the pTAT-vector were digested with $\mathrm{NcoI}$ and EcoR1, ligated, and used for the transformation of Escherichia coli DH5a competent cells (Invitrogen, Carlsbad, Calif., USA). Colonies were selected and the DNA was extracted using a DNA Maxi Prep from Marlingen Biosciences (Rockville, Md., USA).

E. coli BL21-AI cells (Invitrogen) were transformed to overexpress the recombinant TAT fusion proteins. Purification of TATsyntaxin-4 or TAT-SNAP-23 was performed by sonication and lysis of the bacterial pellet with a denaturing buffer $(7 \mathrm{M}$ urea, $0.5 \mathrm{M}$ $\mathrm{NaCl}, 50 \mathrm{mM} \mathrm{NaPO}_{4}, \mathrm{pH} 8,20 \mathrm{~mm}$ imidazole), followed by protein separation from the supernatant by Ni-NTA beads (Invitrogen). Protein eluted from the beads was dialyzed against $10 \%$ glycerol, $0.01 \%$ Triton $\mathrm{X}-100$ in PBS, $\mathrm{pH} 7.4$, and stored at $-80^{\circ} \mathrm{C}$ until use.

\section{Exocytosis}

Exocytosis of secretory vesicles, and specific and azurophilic granules was determined by measuring the increase in plasma membrane binding of FITC-conjugated monoclonal anti-CD35 (clone E11; Pharmingen, San Diego, Calif., USA), FITC-conjugated monoclonal anti-CD66b (clone CLB-B13.9; Accurate Chemical, Westbury, N.Y., USA), and FITC-conjugated anti-CD63 (clone AHN16.1/46-4-5; Ancell Corporation, Bayport, Minn., USA), respectively, on $4 \times 10^{6} / \mathrm{ml}$ neutrophils using a FACSCalibur flow cytometer (Becton Dickinson, Franklin Lakes, N.J., USA) as previously described $[9,15]$. Exocytosis of gelatinase granules was determined by ELISA for matrix metalloproteinase-9 (R\&D Systems) as previously described [15].

\section{Phagocytosis and Respiratory Burst Activity}

To measure $\mathrm{H}_{2} \mathrm{O}_{2}$ production, neutrophils $\left(4 \times 10^{6}\right.$ cells $\left./ \mathrm{ml}\right)$ were incubated with $2^{\prime}, 7^{\prime}$-dichlorofluorescin diacetate (final concentration 0.5 mM; Molecular Probes/Invitrogen, Carlsbad, Calif., USA) for $10 \mathrm{~min}$ at $37^{\circ} \mathrm{C}$. Fifty microliters of cell suspension were sampled before and $10 \mathrm{~min}$ after the addition of $50 \mu \mathrm{l}$ of opsonized, propidium iodide-labeled Staphylococcus aureus (final concentration $\sim 10^{8}$ bacteria $/ \mathrm{ml}$ ). Samples were analyzed for uptake of labeled bacteria and oxidation of $2^{\prime}, 7^{\prime}$-dichlorofluorescein diacetate to fluorescent $2^{\prime}, 7^{\prime}$-dichlorofluorescein by flow cytometry as previ- 
ously described [9]. Extracellular superoxide release was determined as superoxide dismutase-inhibitable ferricytochrome $\mathrm{c}$ reduction measured spectrophotometrically, as previously described [16]. Briefly, neutrophils $\left(4 \times 10^{6} / \mathrm{ml}\right)$ were suspended in KrebsRinger phosphate buffer containing calcium and magnesium and $80 \mu \mathrm{M}$ ferricytochrome $\mathrm{c}$. After stimulation of $\mathrm{O}_{2}^{-}$production, the reaction was stopped by placing the tubes on ice and pelleting the cells by centrifugation at $4{ }^{\circ} \mathrm{C}$. Superoxide production was quantified using the change in absorbance of the supernatant at $550 \mathrm{~nm}$ and expressed as nanomoles of $\mathrm{O}_{2}^{-}$per $4 \times 10^{6}$ cells using an extinction coefficient of $2.1 \times 10^{4} / \mathrm{M} / \mathrm{cm}$.

\section{p47 $7^{\text {phox }}$ Translocation}

Neutrophils $\left(2 \times 10^{7}\right.$ cells $\left./ \mathrm{ml}\right)$ were suspended in Krebs-Ringer phosphate buffer containing calcium and magnesium and exposed to different stimuli at $37^{\circ} \mathrm{C}$. Isolation of the cell membrane fraction was then performed as previously described [17] with some minor modifications. Cells were pelleted at $4,000 \mathrm{rpm}$ for $1 \mathrm{~min}$ at $4{ }^{\circ} \mathrm{C}$, and rapidly lysed by resuspending the pellet in ice-cold extraction buffer [20 mM Tris- $\mathrm{HCl}, \mathrm{pH}$ 7.8, $10 \mathrm{mM}$ HEPES, $25 \mathrm{mM} \mathrm{NaCl}$, $2 \mathrm{mM}$ EDTA, $10 \mathrm{~mm}$ EGTA, and $1 \%(\mathrm{w} / \mathrm{w})$ protease inhibitor cocktail] followed by sonication using three 5 -second cycles at $4{ }^{\circ} \mathrm{C}$. Cell debris and nuclei were removed by centrifugation at $700 \mathrm{~g}$ for 10 $\min$ at $4^{\circ} \mathrm{C}$. The supernatant was transferred to ultracentrifugation tubes and centrifuged at $100,000 \mathrm{~g}$ for $30 \mathrm{~min}$ at $4^{\circ} \mathrm{C}$. The pellet was resuspended in ice-cold extraction buffer and centrifuged at $100,000 \mathrm{~g}$ for another $30 \mathrm{~min}$ at $4^{\circ} \mathrm{C}$. After centrifugation, the pellet containing the membrane fraction was resuspended in ice-cold buffer (PBS, 0.5\% Triton X-100, 1 mM PMSF), thoroughly mixed, and incubated for $20 \mathrm{~min}$ at $4^{\circ} \mathrm{C}$. Membrane fractions were stored at $-80^{\circ} \mathrm{C}$ until used. For detection of membrane translocation of p $47^{\text {phox }}$, membrane proteins were separated by $10 \%$ SDS-PAGE, transferred to nitrocellulose, and immunblotted with anti-p $47^{\text {phox }}$. Protein bands were detected by chemiluminescence and quantified by densitometry of immunoblots with an Epson 9940 scanner using ImageJ 1.44p processing software [18].

\section{Statistical Analysis}

The ability of the fusion proteins to inhibit, or latrunculin A to enhance, exocytosis and respiratory burst activity was examined by fitting a sigmoidal equation to the experimental data (SigmaPlot for Windows, version 11; Systat Software, San Jose, Calif., USA). The $\mathrm{IC}_{50}$ or $\mathrm{EC}_{50}$ was determined as the concentration of fusion protein or latrunculin A that produced $50 \%$ of the maximal effect of the fusion protein or latrunculin A on exocytosis or respiratory burst activity. The relationship between inhibition of exocytosis and inhibition of respiratory burst priming was examined by linear regression (SPSS 12 for Windows; SPSS, Chicago, Ill., USA). The regression line was compared to the line of identity by determining if the $95 \%$ confidence intervals for the slope and intercept of the regression line included 1 and 0 , respectively. Differences in $\mathrm{p} 47^{\text {phox }}$ translocation, exocytosis, and respiratory burst activity in the presence or absence of fusion proteins, Pin1 inhibitor, or MAPK inhibitors were examined by analysis of variance (SPSS 12 for Windows). Where significant differences were identified, differences between individual groups were determined with the Student-Newman-Keuls post hoc test or a Bonferroni correction, as appropriate. When required, a log transformation was performed to normalize the data. Statistical significance was defined as $\mathrm{p}<$ 0.05. All data are expressed as means \pm SEM.

Mechanisms of Neutrophil Priming

\section{Results}

The ability of TAT-SNAP-23, TAT-syntaxin-4, and TAT-control to inhibit basal, stimulated, and primed respiratory burst activity was examined by measuring fMLF-stimulated superoxide release and phagocytosisstimulated $\mathrm{H}_{2} \mathrm{O}_{2}$. For superoxide release, neutrophils were pretreated for $10 \mathrm{~min}$ with $42 \mathrm{nM}$ TAT-SNAP-23, 53 nM TAT-syntaxin-4, or 53 nM TAT-control before being left unprimed or primed with $2 \mathrm{ng} / \mathrm{ml}$ TNF for $10 \mathrm{~min}$. Cells were then stimulated for 5 min with $300 \mathrm{nM} \mathrm{fMLF}$, the lowest concentration to stimulate maximal superoxide release [15]. Figure 1a shows that fMLF stimulates a modest increase in superoxide release above the very low basal release, and priming with TNF increases the response to fMLF 3- to 4-fold. Neither basal nor fMLFstimulated superoxide release was altered by pretreatment with any of the TAT fusion proteins. On the other hand, pretreatment with TAT-SNAP-23 or TAT-syntaxin-4, but not TAT-control, markedly reduced the ability of TNF to prime superoxide release. Pretreatment with those TAT fusion proteins had no effect on $\mathrm{H}_{2} \mathrm{O}_{2}$ production (fig. 1b) or phagocytosis (fig. 1c) in unprimed cells. Priming with TNF resulted in a small increase in phagocytosis that was not affected by pretreatment with any of the TAT fusion proteins (fig. 1c). Priming with TNF resulted in a 2-fold increase in $\mathrm{H}_{2} \mathrm{O}_{2}$ production that was markedly reduced by pretreatment with TAT-SNAP-23 and TAT-syntaxin-4 (fig. 1b). Although TNF was able to prime neutrophils pretreated with TAT-control, priming in the presence of TAT-control was significantly less than priming observed in control cells. In separate experiments, addition of $47 \mathrm{nM}$ TAT-SNAP-23, $60 \mathrm{nM}$ TATsyntaxin- 4 , and $60 \mathrm{nM}$ TAT-control, alone, after ferricytochrome $\mathrm{c}$ showed that none of the fusion proteins stimulated superoxide production (data not shown).

To compare the ability of TAT-SNAP-23 and TATsyntaxin-4 to inhibit neutrophil exocytosis, we determined the ability of increasing concentrations of the two fusion proteins to inhibit fMLF-stimulated exocytosis of each of the four granule subsets. Figure 2 shows the concentration-inhibition curves for TAT-SNAP-23. TATSNAP-23 induces a concentration-dependent inhibition of exocytosis of secretory vesicles, gelatinase granules, and specific granules (fig. $2 \mathrm{a}-\mathrm{c}$ ). Little or no inhibition of azurophilic granule exocytosis was noted with TATSNAP-23 (fig. 2d). TAT-syntaxin-4 inhibited exocytosis of all four granules subsets (fig. 3). The maximum percentages of inhibition of fMLF-stimulated exocytosis and $\mathrm{IC}_{50}$ of each TAT fusion protein for each granule subset

J Innate Immun 2013;5:277-289 


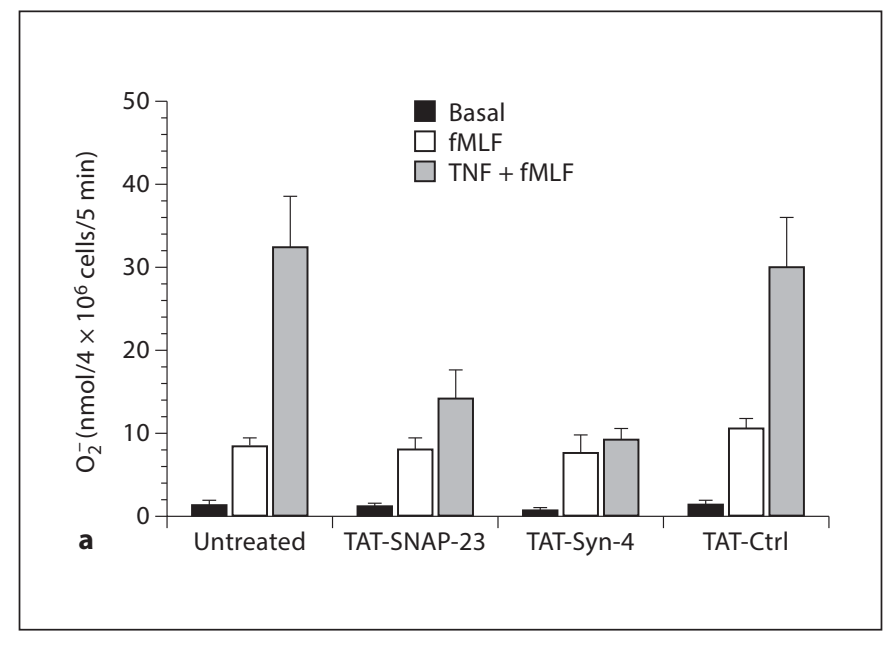

Fig. 1. Inhibition of priming by TAT-SNAP-23 and TAT-syntaxin (Syn)-4. a Neutrophils $\left(4 \times 10^{6} / \mathrm{ml}\right)$ were incubated with or without 42 nM TAT-SNAP-23, 53 nM TAT-syntaxin-4, or 53 nM TATcontrol (Ctrl) for $10 \mathrm{~min}$ prior incubation with or without TNF ( $2 \mathrm{ng} / \mathrm{ml}$ ) for $10 \mathrm{~min}$, followed by stimulation of superoxide release with $300 \mathrm{nM}$ fMLF for $5 \mathrm{~min}$. Results of superoxide release in nanomoles of reduced ferricytochrome $\mathrm{c} / 4 \times 10^{6}$ cells $/ 5 \mathrm{~min}$ are presented as mean \pm SEM for $5-11$ experiments. b Neutrophils $(4 \times$ $10^{6} \mathrm{cell} / \mathrm{ml}$ ) were incubated with $0.5 \mathrm{mM} 2^{\prime}, 7^{\prime}$-dichlorofluorescein diacetate for $10 \mathrm{~min}$ at $37^{\circ} \mathrm{C}$ prior to a 10 -min incubation with or without $42 \mathrm{nM}$ TAT-SNAP-23 or $53 \mathrm{~nm}$ TAT-syntaxin-4, 2nd then incubated with or without TNF $(2 \mathrm{ng} / \mathrm{ml})$ for $10 \mathrm{~min}$. Fifty microliters of cell suspension were sampled before and 10 min after the addition of opsonized, propidium iodide-labeled $S$. aureus. Uptake of labeled bacteria and oxidation of $2^{\prime}, 7^{\prime}$-dichlorofluorescein diacetate to fluorescent $2^{\prime}, 7^{\prime}$-dichlorofluorescein were measured by flow cytometry. $\mathrm{H}_{2} \mathrm{O}_{2}$ production (b) and phagocytosis (c) are expressed as mean \pm SEM in mean channel fluorescence units (mcf) for 4-13 separate experiments.
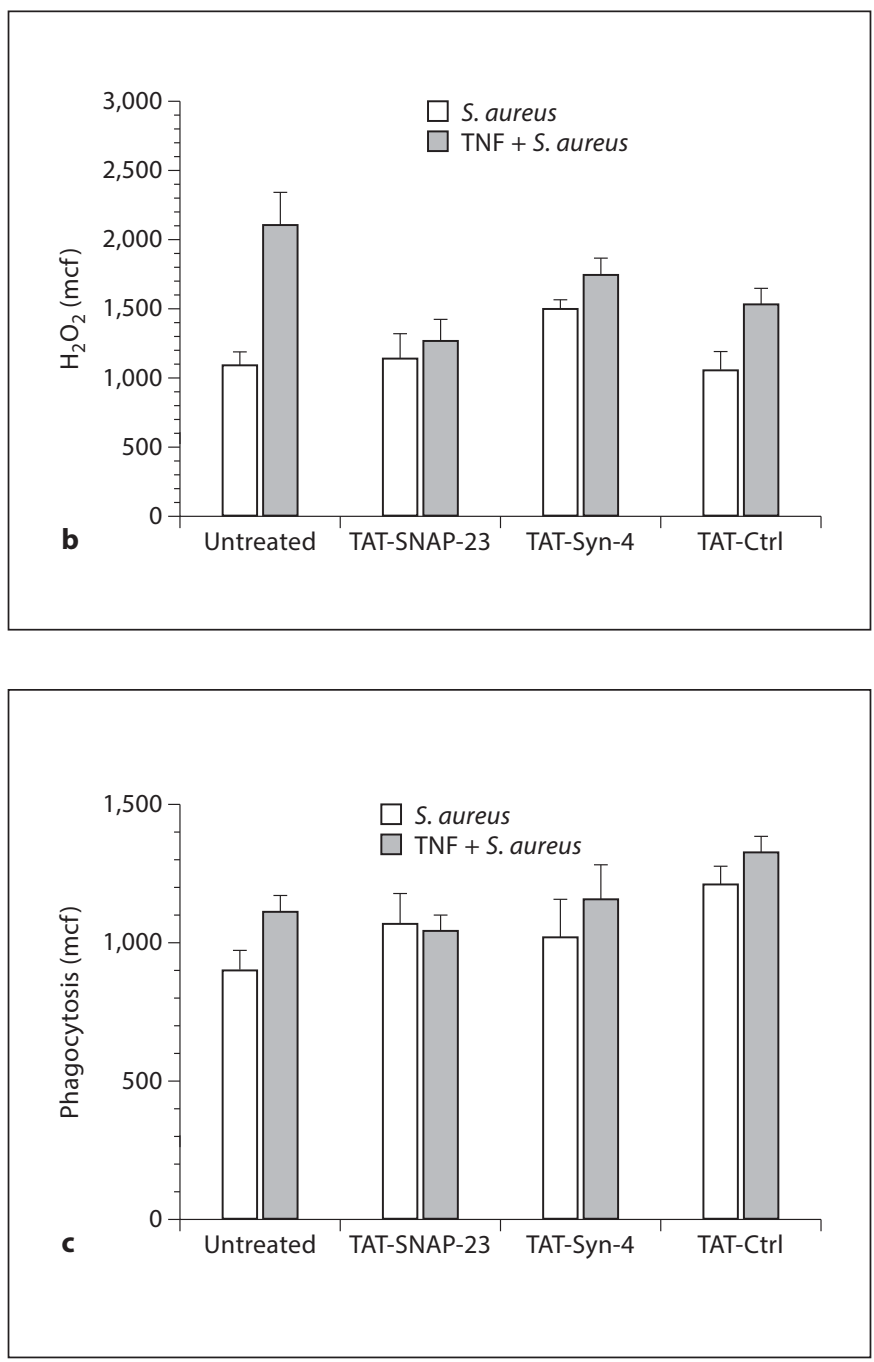

Table 1. Maximum inhibition and $\mathrm{IC}_{50}$ of TAT fusion proteins for granule subset exocytosis and respiratory burst activity $(\mathrm{ND}=$ not determined)

\begin{tabular}{|c|c|c|c|c|}
\hline & \multicolumn{2}{|l|}{ TAT-SNAP-23 } & \multicolumn{2}{|l|}{ TAT-syntaxin-4 } \\
\hline CD35 (secretory vesicles) & $82 \%$ & 27 & $84 \%$ & 40 \\
\hline Gelatinase (gelatinase granules) & $100 \%$ & 30 & $80 \%$ & 31 \\
\hline CD66b (specific granules) & $57 \%$ & 37 & $50 \%$ & 31 \\
\hline \multicolumn{5}{|l|}{ Respiratory burst activity } \\
\hline Superoxide & $72 \%$ & 28 & $76 \%$ & 29 \\
\hline Hydrogen peroxide & $88 \%$ & 34 & $72 \%$ & 36 \\
\hline
\end{tabular}




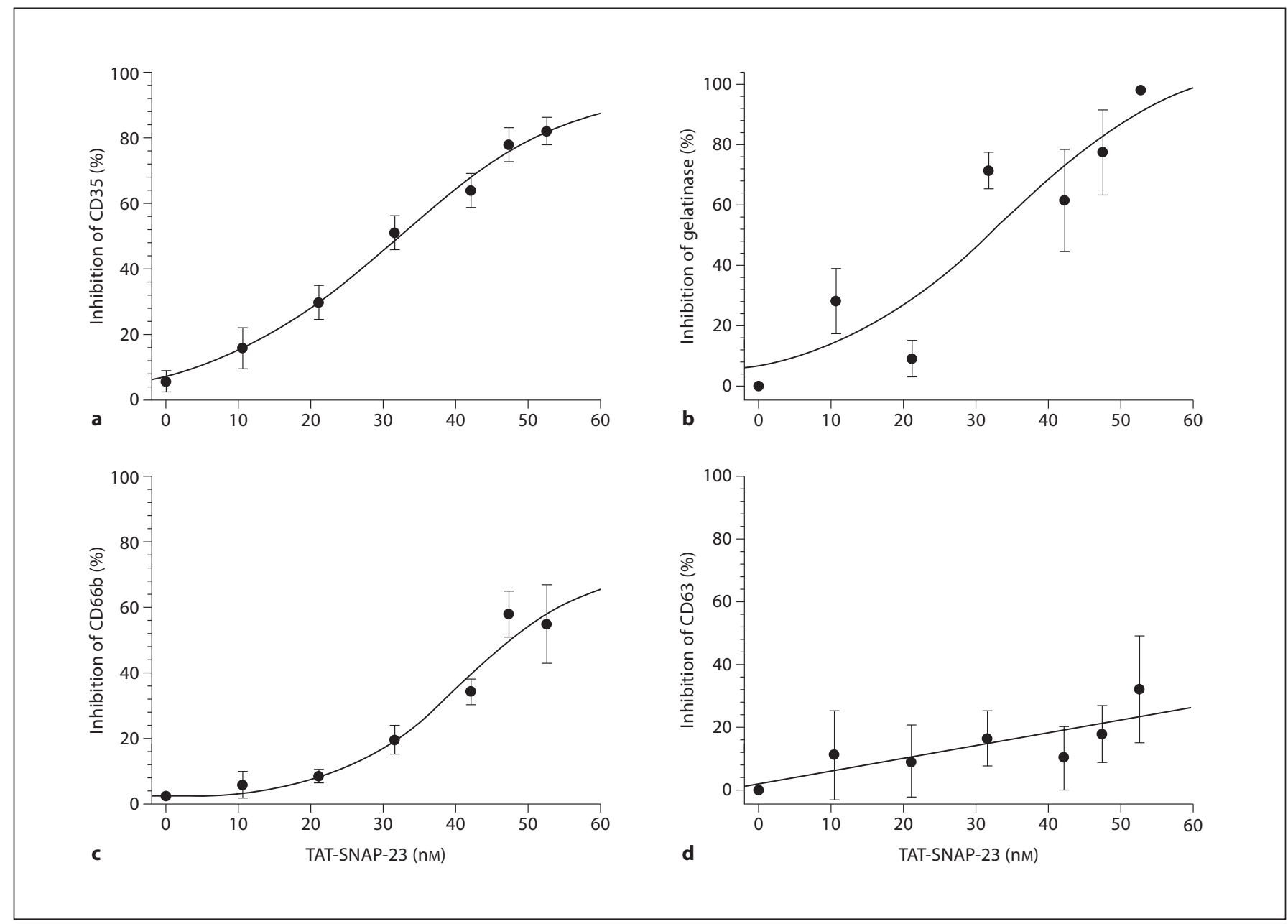

Fig. 2. Concentration inhibition of granule subset exocytosis by TAT-SNAP-23. Neutrophils $\left(4 \times 10^{6} / \mathrm{ml}\right)$ were incubated without or with TAT-SNAP-23 at concentrations from 11 to $53 \mathrm{nM}$ for 10 $\mathrm{min}$, then treated with or without fMLF at $300 \mathrm{nM}$ for $5 \mathrm{~min}$. For experiments examining CD63 expression, cells were pretreated with latrunculin $\mathrm{A}(1 \mu \mathrm{M})$ for $30 \mathrm{~min}$. Percent inhibition was calculated as $100 \times\left(\mathrm{C}_{0}-\mathrm{C}_{\mathrm{TAT}}\right) / \mathrm{C}_{0}$, where $\mathrm{C}_{0}$ is the value of the measured parameter in the absence of TAT-SNAP-23 and $\mathrm{C}_{\mathrm{TAT}}$ is the value of the measured parameter in the presence of the indicated concentration of TAT-SNAP-23. a Inhibition of exocytosis of secretory vesicles was determined using plasma membrane expres-

are presented in table 1 . Those data show that both fusion proteins maximally inhibited fMLF-stimulated secretory vesicle and gelatinase granule exocytosis by $80 \%$, while the maximum inhibition of specific granule exocytosis was between 50 and $60 \%$. TAT-syntaxin- 4 inhibited azurophilic granule exocytosis by about $80 \%$. $\mathrm{IC}_{50}$ values for TAT-SNAP-23 ranged from 27 to $37 \mathrm{nM}$, and $\mathrm{IC}_{50}$ values for TAT-syntaxin- 4 ranged from 31 to $44 \mathrm{nM}$. sion of CD35. Results are presented as means \pm SEM for 12 separate experiments. $\mathbf{b}$ Inhibition of exocytosis of gelatinase granules was determined using extracellular release of gelatinase. Results are presented as means \pm SEM for 5 separate experiments. c Inhibition of exocytosis of specific granules was determined using plasma membrane expression of CD66b. Results are presented as means \pm SEM for 12 separate experiments. $\mathbf{d}$ Inhibition of exocytosis of azurophilic granules was determined using plasma membrane expression of CD63. Results are presented as means \pm SEM for 4 separate experiments.

To determine the ability of each TAT fusion protein to inhibit TNF-induced priming of respiratory burst activity, neutrophils were incubated with various concentrations of TAT-SNAP-23 or TAT-syntaxin-4 prior to a 10min exposure to $2 \mathrm{ng} / \mathrm{ml}$ TNF; respiratory burst activity was then measured as fMLF-stimulated superoxide release or phagocytosis-stimulated $\mathrm{H}_{2} \mathrm{O}_{2}$ production. Figure 4 depicts the dose inhibition curves of superoxide re- 

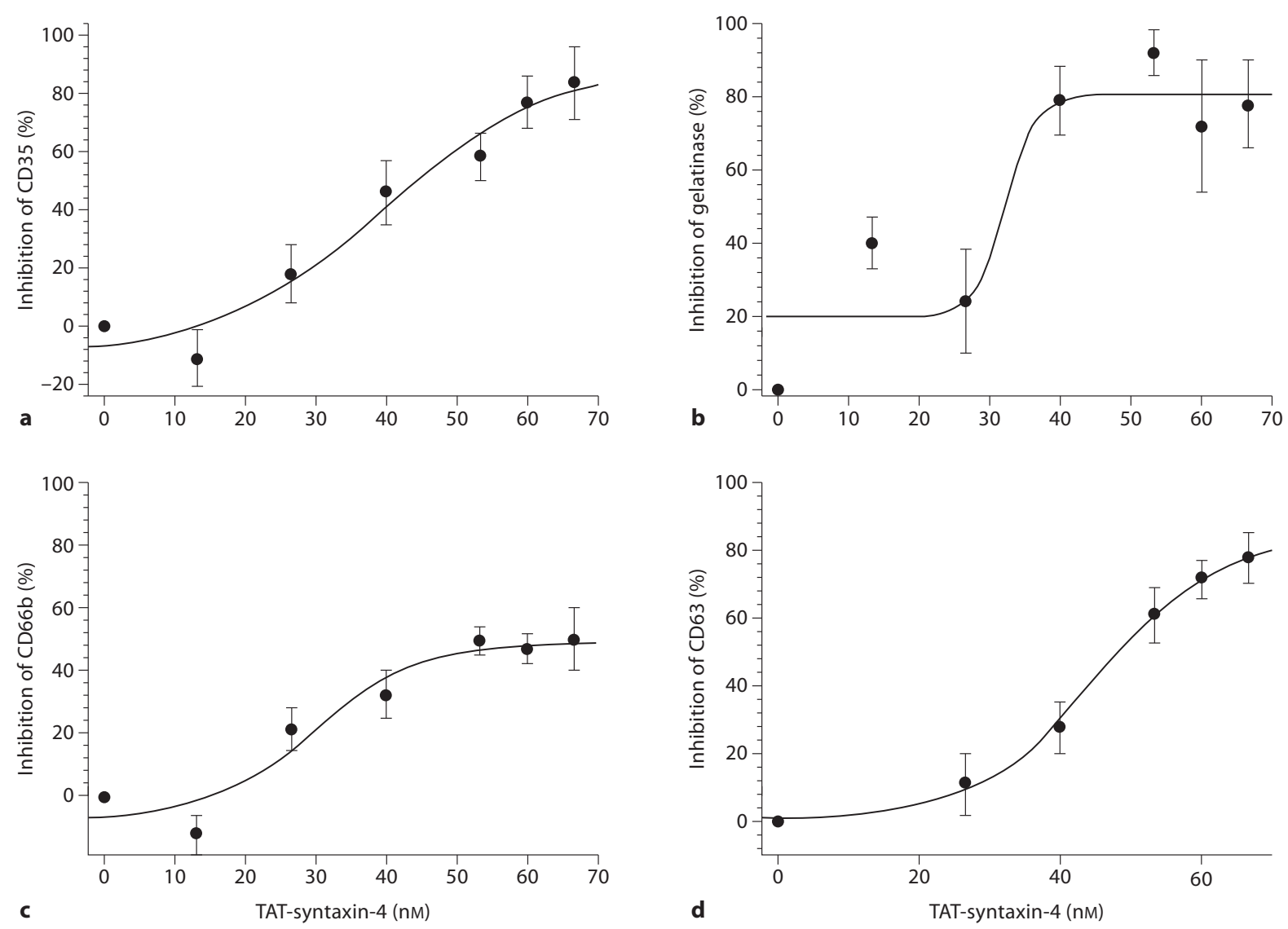

Fig. 3. Concentration inhibition of granule subset exocytosis by TAT-syntaxin- 4 . Neutrophils $\left(4 \times 10^{6} / \mathrm{ml}\right)$ were incubated without or with TAT-syntaxin- 4 at concentrations from 13 to $67 \mathrm{nM}$ for 10 $\mathrm{min}$, then treated with or without fMLF at $300 \mathrm{nM}$ for $5 \mathrm{~min}$. For experiments examining CD63 expression, cells were pretreated with latrunculin A $(1 \mu \mathrm{M})$ for 30 min. Percent inhibition was calculated as described in figure 1. a Inhibition of exocytosis of secretory vesicles was determined using plasma membrane expression of CD35. Results are presented as means \pm SEM for 6 separate ex-

periments. b Inhibition of exocytosis of gelatinase granules was measured using extracellular release of gelatinase. Results are presented as means \pm SEM for 5 separate experiments. c Inhibition of exocytosis of specific granules was determined using plasma membrane expression of CD66b. Results are presented as means \pm SEM for 6 separate experiments. d Inhibition of exocytosis of azurophilic granules was determined using plasma membrane expression of CD63. Results are presented as means \pm SEM for 8 separate experiments.

lease and $\mathrm{H}_{2} \mathrm{O}_{2}$ production for TAT-SNAP-23 and TATsyntaxin-4, respectively. Table 1 presents the maximum percent inhibition of respiratory burst activity and $\mathrm{IC}_{50}$ for both fusion proteins. Priming was inhibited by $72-$ $88 \%$, with an $\mathrm{IC}_{50}$ of approximately $30 \mathrm{nM}$ in all four conditions.

The ability of both TAT fusion proteins to inhibit exocytosis and priming suggested a causative relationship. If such a causative relationship exists, we reasoned that enhanced exocytosis would recapitulate priming of respiratory burst activity. Based on our previous report that disruption of the neutrophil actin cytoskeleton by latruncu-

lin A enhanced the rate and extent of AMLF-stimulated exocytosis [15], we compared the effect of various concentrations of latrunculin A on fMLF-stimulated superoxide release. Figure 5a shows a significant, 4 -fold increase in AMLF-stimulated superoxide release following pretreatment with optimal concentrations of latrunculin A $\left(\mathrm{EC}_{50}\right.$ of $\left.0.095 \mu \mathrm{M}\right)$. To confirm that the enhanced superoxide release produced by pretreatment with latrunculin A was due to exocytosis, neutrophils were incubated with or without TAT-syntaxin-4 prior to pretreatment with $10 \mu \mathrm{M}$ latrunculin $\mathrm{A}$, followed by stimulation with fMLF. Figure $5 \mathrm{~b}$ reveals that TAT-syntaxin- 4 inhibited 


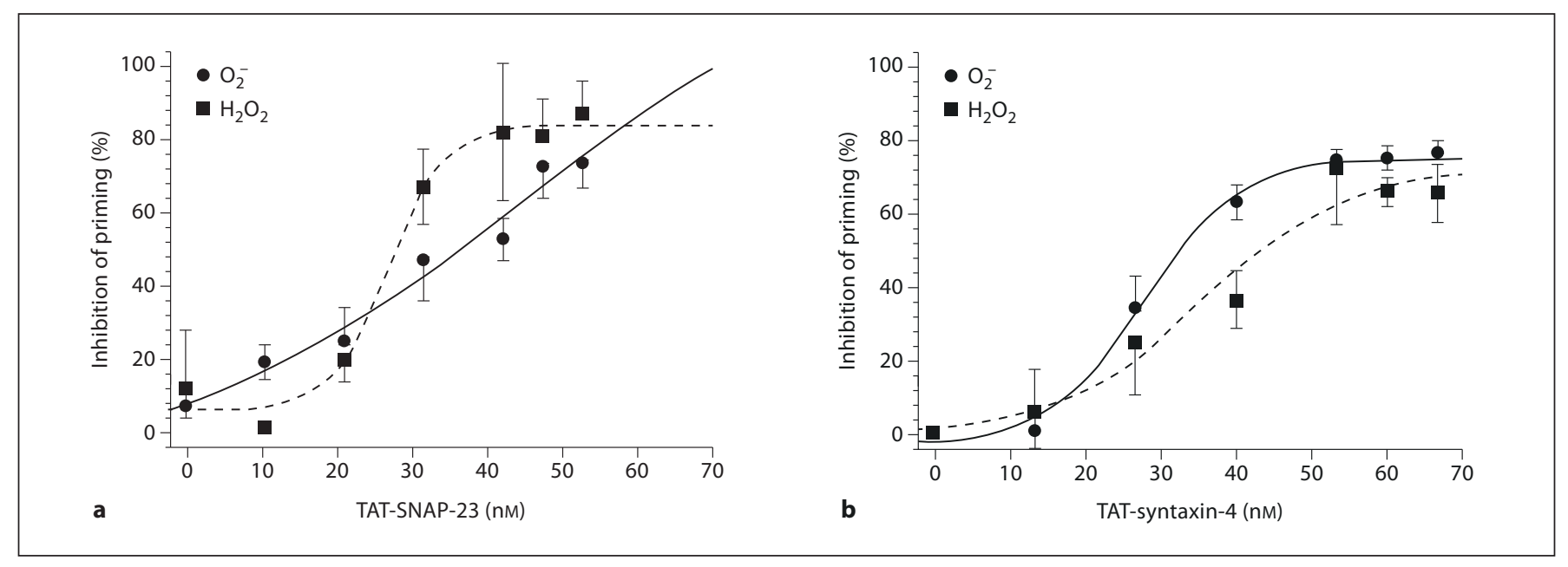

Fig. 4. Concentration inhibition of neutrophil priming by TAT fusion proteins. Neutrophils $\left(4 \times 10^{6} / \mathrm{ml}\right)$ were incubated with or without the indicated concentrations of TAT-SNAP-23 or TATsyntaxin- 4 for $10 \mathrm{~min}$ prior to priming with TNF ( $2 \mathrm{ng} / \mathrm{ml}$ for 10 $\mathrm{min}$ ), followed by stimulation of superoxide release with $300 \mathrm{nM}$
fMLF for 5 min or stimulation of $\mathrm{H}_{2} \mathrm{O}_{2}$ release by phagocytosis of $S$. aureus for $10 \mathrm{~min}$. Percent inhibition was calculated as described in figure 1. a Inhibition of priming by TAT-SNAP-23. b Inhibition of priming by TAT-syntaxin-4. Results are presented as means \pm SEM for 4-6 separate experiments. priming of respiratory burst activity by latrunculin $\mathrm{A}$ in a dose-dependent manner with a maximum inhibition of $82 \%$ at 67 nM TAT-syntaxin-4. Similar results were observed with TAT-SNAP-23 (data not shown). We interpret those data to indicate that latrunculin A-induced priming of respiratory burst activity was due primarily to enhanced exocytosis.

To evaluate the role of individual granule subsets in TNF-induced priming of respiratory burst activity, we examined the relationship between inhibition of priming of superoxide or $\mathrm{H}_{2} \mathrm{O}_{2}$ production and inhibition of exocytosis of each granule subset for each concentration of TAT fusion protein by linear regression. The slopes and $y$-intercepts for those plots are shown in table 2. The linear regression lines for inhibition of priming of $\mathrm{H}_{2} \mathrm{O}_{2}$ and superoxide compared to inhibition of exocytosis of secretory vesicles (CD35) or gelatinase granules by TATSNAP-23 and by TAT-syntaxin-4 did not differ from the line of identity. However, the linear regression line for inhibition of specific granule exocytosis (CD66b) and inhibition of hydrogen peroxide priming by TAT-SNAP-23 was significantly different from the line of identity ( $95 \%$ confidence interval for the slope of $0.227-0.892$ ) and, while the slope of the regression line for inhibition of specific granule exocytosis and inhibition of superoxide priming by TAT-SNAP-23 did not significantly differ from the line of identity, the line was shifted to the right with a y-intercept of -11.54. In addition, the linear regres- sion lines for inhibition of specific granule exocytosis versus inhibition of $\mathrm{H}_{2} \mathrm{O}_{2}$ priming and superoxide priming by TAT-syntaxin- 4 were both significantly different from the line of identity (95\% confidence intervals for the slope of $0.537-0.828$ for hydrogen peroxide and $0.549-0.868$ for superoxide). As the inhibition of azurophilic granule exocytosis by TAT-SNAP-23 was minimal, we did not compare that inhibition with inhibition of priming. The slope of the linear regression line for inhibition of azurophilic granule exocytosis (CD63) and inhibition of hydrogen peroxide priming for TAT-syntaxin-4 did not significantly differ from the line of identity, while the plot for inhibition of azurophilic granule exocytosis and superoxide priming was not linear. These results suggest that exocytosis of secretory vesicles and gelatinase granules plays a role in neutrophil priming.

To determine if inhibition of exocytosis altered translocation of the cytosolic components of the NADPH oxidase, we evaluated the effect of TAT-SNAP-23 on translocation of $\mathrm{p} 47^{\mathrm{phox}}$ to the plasma membrane of primed neutrophils after fMLF stimulation. Figure 6 shows a representative immunoblot (fig. 6a) and the densitometric analysis of multiple experiments (fig. 6b). Pretreatment with TAT-SNAP-23 or TAT-control failed to alter the translocation of $\mathrm{p} 47^{\mathrm{phox}}$ in neutrophils primed with TNF and then stimulated with fMLF. Thus, translocation of $\mathrm{p} 47^{\text {phox }}$ appears to be independent of the amount of cytochrome $b_{558}$ in the plasma membrane. 


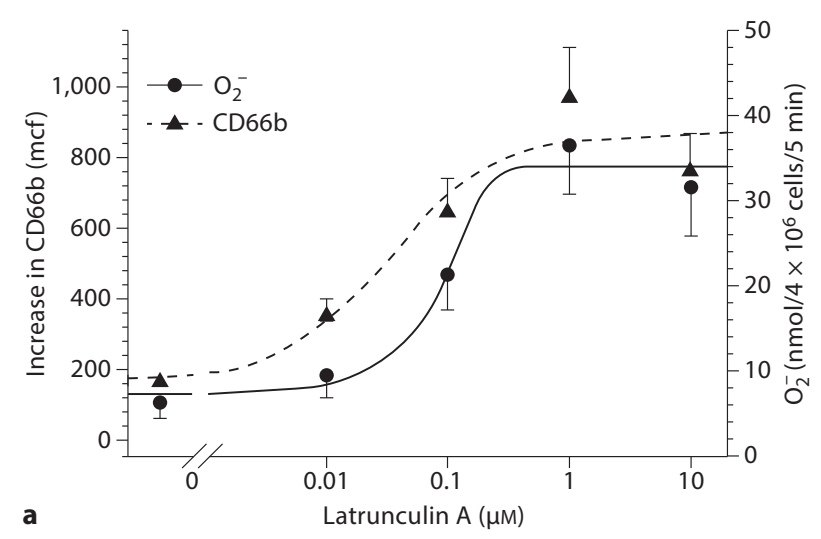

Fig. 5. Disruption of the actin cytoskeleton with latrunculin A enhances exocytosis and induces priming. a Effect of pretreating neutrophils with increasing concentrations of latrunculin A on exocytosis of specific granules (CD66b) and on fMLF-stimulated superoxide release. Neutrophils $\left(4 \times 10^{6} / \mathrm{ml}\right)$ were incubated with the indicated concentrations of latrunculin A for $30 \mathrm{~min}$ prior to stimulation with $300 \mathrm{nM}$ fMLF for $5 \mathrm{~min}$. Superoxide release and CD66b expression are presented as means \pm SEM for 6 separate

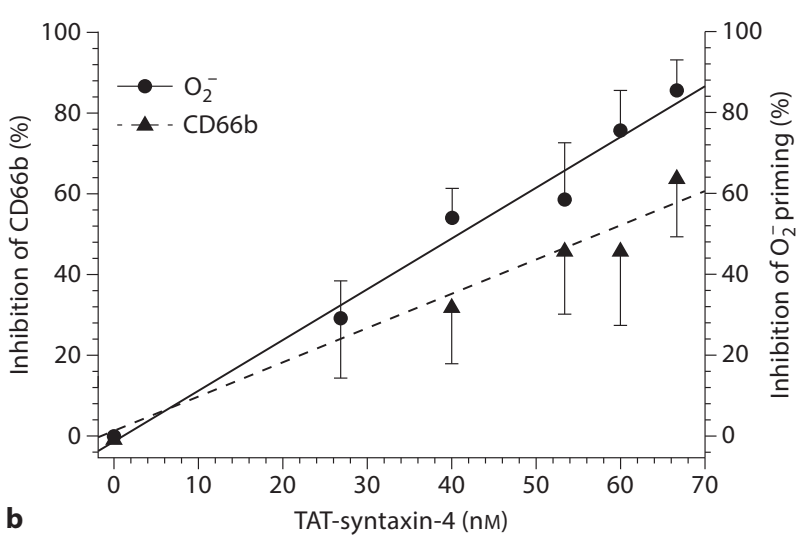

experiments. $\mathrm{mcf}=$ Mean channel fluorescence units. $\mathbf{b}$ Concentration inhibition of latrunculin A-induced exocytosis and priming by TAT-syntaxin-4. Neutrophils were incubated with $10 \mathrm{M}$ latrunculin A for $30 \mathrm{~min}$ and then incubated with the indicated concentrations of TAT-syntaxin-4 prior to stimulation of superoxide release and CD66b expression with $300 \mathrm{nM}$ fMLF for $5 \mathrm{~min}$. Results are presented as means \pm SEM for 5 separate experiments.

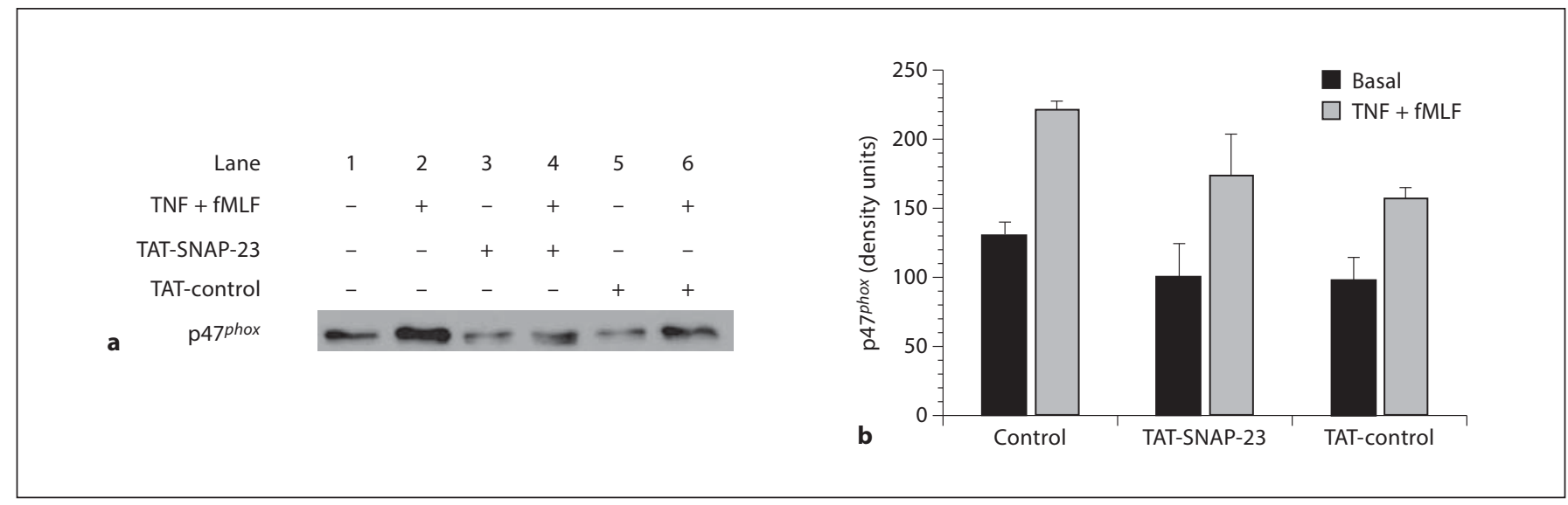

Fig. 6. Effect of inhibition of exocytosis on translocation of $\mathrm{p} 47^{\mathrm{phox}}$. a Representative immunoblot for $\mathrm{p} 47^{\text {phox }}$ of membrane fractions obtained from unstimulated cells or cells primed with $2 \mathrm{ng} / \mathrm{ml} \mathrm{TNF}$ for $10 \mathrm{~min}$ followed by stimulation with $300 \mathrm{nM}$ fMLF for $5 \mathrm{~min}$ in the presence or absence of $47 \mathrm{nM}$ TAT-SNAP-23 or $60 \mathrm{nM}$ TAT-

Boussetta et al. [12] recently reported that p38 MAPKmediated phosphorylation of $\mathrm{p} 47^{\text {phox }}$ during TNF priming resulted in enhanced binding of the prolyl isomerase Pin1, and that the isomerase activity was necessary for enhanced $\mathrm{p} 47^{\text {phox }}$ translocation to the plasma membrane. To determine if the Pin 1 contribution to priming was in- control prior to isolation of membrane fractions. b Mean \pm SEM densitometric analysis of 4 separate experiments showing that TAT-SNAP-23 and TAT-control had no effect on p4 $7^{\text {phox }}$ translocation induced by priming and stimulation.

dependent of exocytosis, we compared the effect of inhibition of Pin 1 activity on granule exocytosis and priming. Juglone inhibited TNF priming of superoxide release by $56 \pm 9 \%$ (fig. 7a). Figure 7b shows that juglone pretreatment had no effect on TNF-stimulated exocytosis, measured as the increase in plasma membrane expression of 


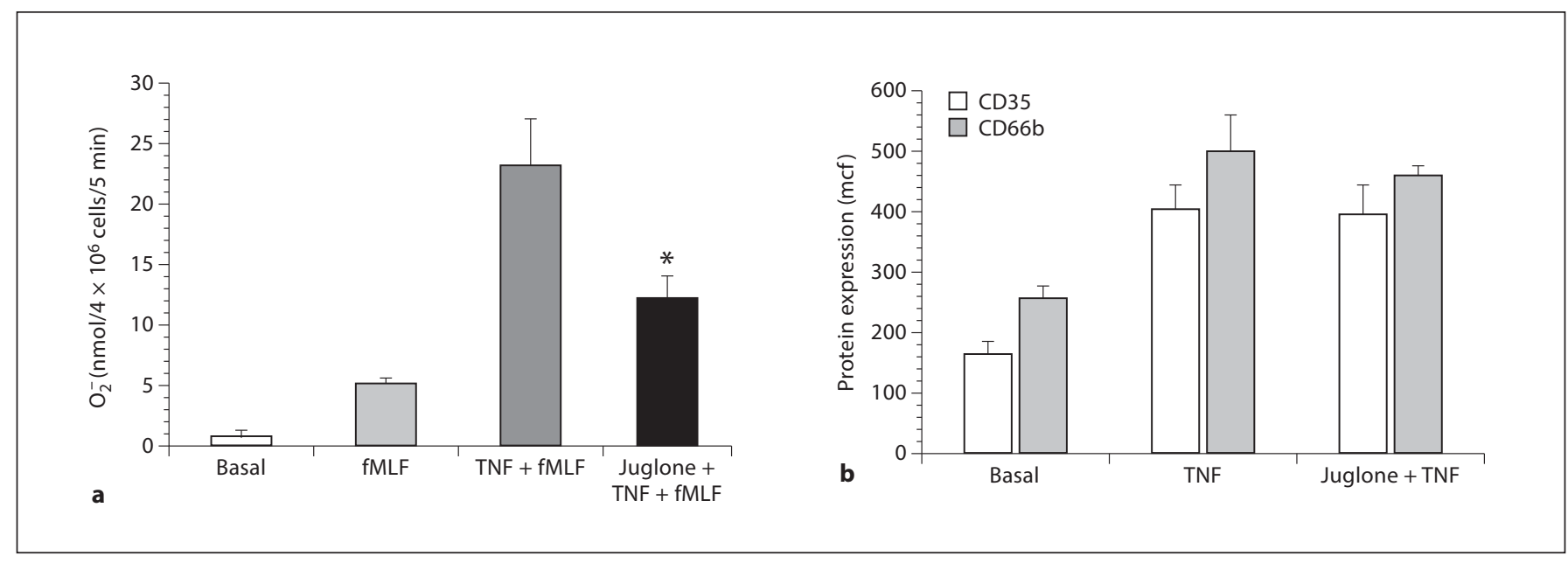

Fig. 7. Effect of inhibition of Pin 1 on priming and exocytosis. a Neutrophils $\left(4 \times 10^{6} / \mathrm{ml}\right)$ were incubated with $250 \mu \mathrm{M}$ juglone for $30 \mathrm{~min}$ at $37^{\circ} \mathrm{C}$ prior to incubation with or without $2 \mathrm{ng} / \mathrm{ml} \mathrm{TNF}$ for $10 \mathrm{~min}$, then with or without $300 \mathrm{nM}$ fMLF for $5 \mathrm{~min}$. Superoxide release is presented as mean $\pm \mathrm{SEM} \mathrm{nmol} / 4 \times 10^{6}$ cells of reduced ferricytochrome $\mathrm{c}$ for 5 separate experiments. * $\mathrm{p}<0.05$

CD35 (secretory vesicles) and CD66b (specific granules). These data suggest that prolyl isomerase activity is necessary for neutrophil priming, and that the contribution of prolyl isomerase is independent of exocytosis.

We showed previously that TNF-induced priming of neutrophil respiratory burst activity and stimulation of exocytosis were dependent on p38 MAPK activation [9]. MAPKAPK2 is activated by 338 MAPK and mediates a number of p38 MAPK-dependent events in neutrophils and other cells [19-21]. Thus, the contribution of p38 MAPK and MAPKAPK2 to priming was determined using pharmacologic inhibitors. Inhibition of p38 MAPK significantly decreased TNF-induced priming of respiratory burst activity and exocytosis of secretory vesicles and specific granules, while inhibition of MAPKAPK2 had no effect (fig. 8). TNF did not stimulate exocytosis of azurophilic granules. These data suggest that the role of $\mathrm{p} 38$ MAPK in priming is due to direct phosphorylation of substrates, not to activation of MAPKAPK2.

\section{Discussion}

Understanding the molecular mechanisms of priming the neutrophil respiratory burst has the potential to provide approaches to manipulate neutrophil function in a variety of human diseases. Previously proposed mechanisms for priming include granule exocytosis leading to vs. primed cells. b Neutrophils $\left(4 \times 10^{6} / \mathrm{ml}\right)$ were incubated with $250 \mu \mathrm{M}$ juglone for $30 \mathrm{~min}$ at $37^{\circ} \mathrm{C}$ prior to incubation with or without $2 \mathrm{ng} / \mathrm{ml} \mathrm{TNF}$ for $10 \mathrm{~min}$. Expression of CD35 (secretory vesicles) and CD66b (specific granules) is presented as mean \pm SEM for 6 separate experiments. $\mathrm{mcf}=$ Mean channel fluorescence units.

Table 2. Linear correlation between inhibition of exocytosis and inhibition of priming by TAT fusion proteins

\begin{tabular}{|c|c|c|c|c|c|}
\hline & & \multicolumn{2}{|c|}{ Hydrogen peroxide } & \multicolumn{2}{|c|}{ Superoxide } \\
\hline & & $\begin{array}{l}\text { TAT- } \\
\text { SNAP-23 }\end{array}$ & $\begin{array}{l}\text { TAT- } \\
\text { syntaxin-4 }\end{array}$ & $\begin{array}{l}\text { TAT- } \\
\text { SNAP-23 }\end{array}$ & $\begin{array}{l}\text { TAT-syn- } \\
\text { taxin- } 4\end{array}$ \\
\hline \multirow[t]{2}{*}{ CD35 } & Intercept & 9.169 & -0.342 & -0.382 & -9.530 \\
\hline & Slope & 0.765 & 1.073 & 1.133 & 1.045 \\
\hline \multirow[t]{2}{*}{ Gelatinase } & Intercept & 5.197 & 6.85 & -6.410 & -4.040 \\
\hline & Slope & 0.907 & 1.149 & 1.350 & 1.147 \\
\hline \multirow[t]{2}{*}{ CD66b } & Intercept & -2.724 & 3.183 & -11.540 & -5.790 \\
\hline & Slope & $0.559^{*}$ & $0.683^{*}$ & 0.872 & $0.708^{*}$ \\
\hline \multirow[t]{2}{*}{ CD63 } & Intercept & ND & 1.094 & ND & ND \\
\hline & Slope & ND & -6.74 & ND & ND \\
\hline
\end{tabular}

Differences between the intercept and 0 and differences between the slope and 1 (the identity line) were tested by calculating the $95 \%$ confidence interval for the intercept and the slope. A difference was taken as significant when the confidence interval did not include 0 (intercept) or 1 (slope). Significant differences are shown by an asterisk. ND = Not determined.

increased plasma membrane expression of receptors, $G$ proteins, and/or cytochrome $b_{558}[8,9,22-24]$, and enhanced phosphorylation and translocation of cytosolic NADPH oxidase components $[8,11]$. A number of studies have provided evidence supporting a role for granule exocytosis in neutrophil priming [8-10, 25-27], but the 

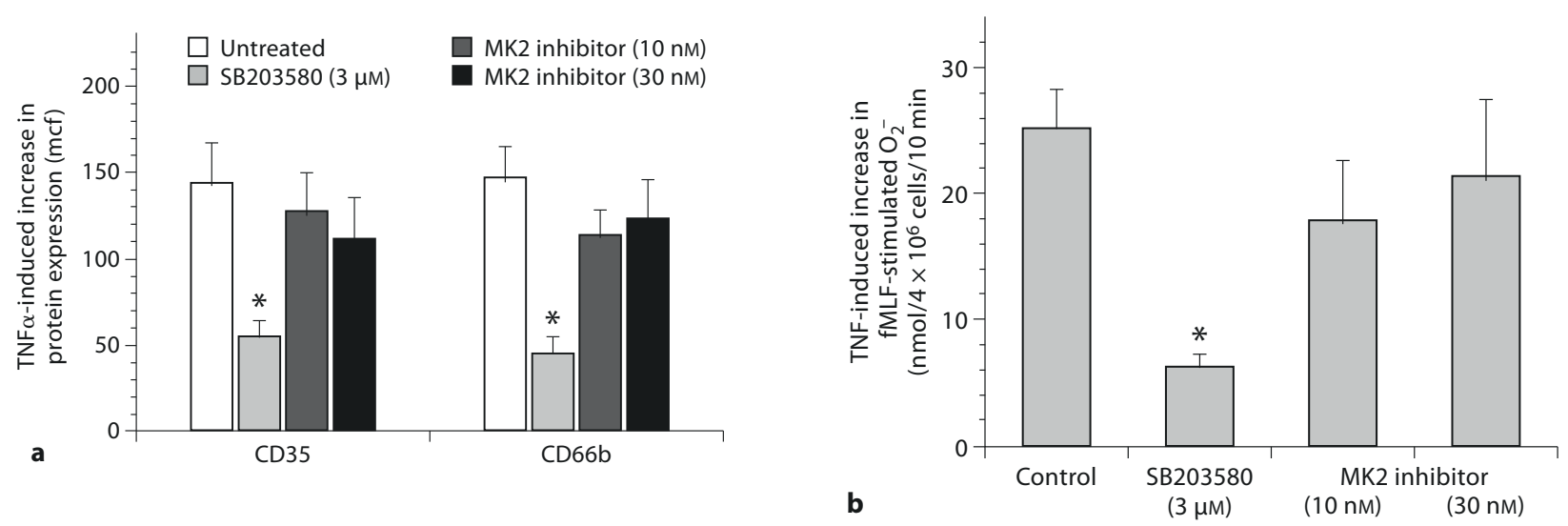

Fig. 8. TNF priming and exocytosis are dependent on p38 MAPK, but not MAPKAPK2 (MK2). a Neutrophils $\left(4 \times 10^{6} / \mathrm{ml}\right)$ were incubated with the p38 MAPK inhibitor, SB203580 $(3 \mu \mathrm{M})$ or MAPKAPK2 inhibitor III ( 10 or $30 \mathrm{nM}$ ) for $30 \mathrm{~min}$ at $37^{\circ} \mathrm{C}$ prior to incubation with $2 \mathrm{ng} / \mathrm{ml} \mathrm{TNF}$ for $10 \mathrm{~min}$. Exocytosis of secretory vesicles and specific granules, measured as plasma membrane expression of CD35 and CD66b, respectively, is presented as mean \pm SEM of the increase above basal expression for 6 separate ex-

inability to selectively block exocytosis prevented a more complete elucidation of that role. The current study used two TAT fusion proteins containing SNARE domains to selectively inhibit exocytosis. Both TAT fusion proteins induced a dose-dependent inhibition of exocytosis of secretory vesicles, and gelatinase and specific granules with similar maximal inhibition and $\mathrm{IC}_{50}$ (table 1). Inhibition of secretory vesicle and gelatinase granule exocytosis was nearly complete, with maximal inhibition ranging from 80 to $100 \%$. On the other hand, maximal inhibition of specific granule exocytosis ranged from 50 to $57 \%$. As previously reported [10], TAT-SNAP-23 failed to inhibit exocytosis of azurophilic granules, while TAT-syntaxin-4 maximally inhibited azurophilic granule exocytosis by almost $80 \%$. The disparity of the effect on azurophilic granule exocytosis is consistent with a previous report by Mollinedo et al. [28] that SNAP-23 mediated gelatinase and specific granule exocytosis, while syntaxin- 4 mediated exocytosis of gelatinase, and specific and azurophilic granules.

Both TAT fusion proteins induced a dose-dependent inhibition of TNF-mediated priming of fMLF-stimulated superoxide release and of phagocytosis-stimulated $\mathrm{H}_{2} \mathrm{O}_{2}$ production. The maximal inhibition of priming and the $\mathrm{IC}_{50}$ for the TAT fusion proteins were similar to those observed for inhibition of secretory vesicle and gelatinase

granule exocytosis (table 1). Although our previous report showed that TAT-SNAP-23 had no effect on signal transduction pathway activation [10], the possibility exists that introduction of SNARE domains has effects independent of granule exocytosis. For example, SNARE proteins have been implicated in the direct regulation of ion channel activities and excitability [29]. Therefore, we sought to manipulate neutrophil exocytosis by another mechanism. We reported previously that disruption of the actin cytoskeleton with latrunculin A enhanced exocytosis of secretory vesicles and gelatinase, specific and azurophilic granules [15]. Based on those observations, we evaluated the effect of latrunculin A-induced exocytosis on fMLF-stimulated respiratory burst activity. Our data show that pretreatment with latrunculin A enhanced fMLF-stimulated respiratory burst activity and exocytosis (fig. 5) and that both of those responses were inhibited by TAT-syntaxin- 4 . Taken together, our data indicate that exocytosis is a necessary component of neutrophil respiratory burst priming.

The dose-dependent inhibition of exocytosis and of priming allowed an evaluation of the role of individual granule subsets in priming. Linear regression analysis indicated a close correlation between inhibition of secretory vesicle and gelatinase granule exocytosis and inhibition of priming for both TAT-SNAP-23 and TAT-syntax- 
in-4 (table 2). Those data suggest that incorporation of a component(s) of secretory vesicle and/or gelatinase granule membranes into the plasma membrane is a necessary event for TNF-mediated priming. Cytochrome $b_{558}$ was shown to be present in plasma membranes and all four subsets of neutrophil granules by proteomic analysis [30, 31]. The relative distribution of cytochrome $b_{558}$ among those compartments was reported to be about $60 \%$ in specific granules, $20 \%$ in gelatinase granules, and $20 \%$ in the secretory vesicle/plasma membrane fraction [32]. Stimulation of neutrophil degranulation by fMLF increased expression in the secretory vesicle/plasma membrane fraction to $30 \%$ of total cell cytochrome $b_{558}$ and reduced expression in the gelatinase granules to $9 \%$, but had no effect on expression in specific granules [32]. Mansfield et al. [33] showed that priming of human neutrophils by G-CSF increased plasma membrane cytochrome $b_{558}$ by $20 \%$, and gelatinase granule exocytosis was the source of that increase. We previously reported that priming was associated with increased plasma membrane expression of cytochrome $b_{558}$, and inhibition of exocytosis prevented that increase during priming $[9,10]$. Evidence supporting a role for increased expression of cytochrome $b_{558}$ in priming was provided by Anrather et al. [34], who reported that NF- $\mathrm{KB}$ mediated an increase in gp91 ${ }^{\text {phox }}$ transcription that resulted in increased production of oxidase activity upon phagocyte stimulation. We postulated that increased cytochrome $b_{558}$ expression would increase oxidase activity by providing an increased number of docking sites for translocation of NADPH oxidase cytosolic components to the plasma membrane. If that hypothesis was true, inhibition of exocytosis with TAT fusion proteins would be associated with a reduction in $\mathrm{p} 47^{\text {phox }}$ translocation. However, our data showed that inhibition of exocytosis by TAT-SNAP-23 had no effect on the translocation of $\mathrm{p} 47^{\text {phox }}$ associated with priming and stimulation. A number of possible explanations could explain those findings. First, cytochrome $b_{558}$ is not the component of granule membranes responsible for priming. Neutrophil granules contain hundreds of proteins in their membranes and matrix, including receptors and signaling proteins that have been suggested to play a role in priming [22-24, 30, 31]. However, we previously reported that inhibition of exocytosis during priming had no effect on activation of signal transduction pathways known to be necessary for priming, suggesting that exocytosis-dependent expression of receptors and components of signal transduction pathways was not responsible for priming [10]. Second, increased plasma membrane expression of cytochrome $b_{558}$ contributes to priming through a mechanism independent of enhanced translocation of cytosolic NADPH oxidase components. Third, differences in translocation of cytosolic oxidase components upon inhibition of exocytosis may be below the detection level of the assay. Only about $10 \%$ of $\mathrm{p} 47^{\text {phox }}$ translocates to the plasma membrane with maximal oxidase activation by phorbol esters [35]. Thus, relatively small differences in the translocation of cytosolic oxidase components may change oxidase activity significantly.

Boussetta et al. [12] recently reported that a cis-trans prolyl isomerase, Pin1, is a mediator of TNF-induced NADPH oxidase priming. Inhibition of TNF-induced Pin1 activity abrogated priming of fMLF-stimulated superoxide release. They proposed that Pin 1 bound to p $47^{\text {phox }}$ that had previously been phosphorylated by $\mathrm{p} 38$ MAPK, thereby inducing a conformational change that facilitated further phosphorylation on other sites of $\mathrm{p} 47^{\text {phox }}$ by PKC. The almost complete abrogation of priming by inhibition of Pin 1 activity in that study and by inhibition of exocytosis in the present study suggested that both events may be necessary for priming or that Pin1 also plays a role in exocytosis. To explore the latter possibility, we evaluated the effect of Pin1 activity on exocytosis and priming. Our data showed that priming of superoxide release by TNF was reduced by almost $60 \%$ by inhibition of Pin1. On the other hand, TNF-stimulated exocytosis was not significantly inhibited. The absence of a significant effect on secretory vesicle exocytosis suggests that the contribution of Pin 1 to priming is independent of exocytosis. Taken together, we interpret our data to indicate that two independent events, Pin1-mediated isomerization of $\mathrm{p} 47^{\text {phox }}$ and exocytosis of secretory vesicles and gelatinase granules, are both required for priming to occur.

A number of studies have shown that the p38 MAPK signal transduction pathway is critical for TNF-induced neutrophil priming and TNF-stimulated exocytosis $[9$, $11,13]$. Direct phosphorylation of $\mathrm{p} 47^{\text {phox }}$ by $\mathrm{p} 38 \mathrm{MAPK}$ has been reported [36] and, as indicated above, that phosphorylation creates a binding motif for Pin1 [12]. MAPKAPK2 is a downstream component of the p38 MAPK signal transduction pathway that is activated by p38 MAPK in human neutrophils [37]. To determine if p38 MAPK activation of MAPKAPK2 plays a role in exocytosis and priming, we examined the effect of pharmacologic inhibition of MAPKAPK2 on exocytosis of secretory vesicles and specific granules and priming of superoxide release. Although there are always concerns about the specificity of pharmacologic inhibitors, our data suggest that participation of the $\mathrm{p} 38$ MAPK pathway in prim- 
ing and exocytosis is independent of MAPKAPK2 activation. Thus, p38 MAPK appears to directly regulate priming through two independent pathways, control of exocytosis and regulation of translocation of cytosolic components of the NADPH oxidase to the plasma membrane. The target(s) of p38 MAPK that controls exocytosis remains to be determined.

\section{Acknowledgments}

This work was supported by grants from the Department of Veterans Affairs Merit Review Board (to K.R.M.), the National Institutes of Health (to S.M.U., 4R00 HL087924), and the American Heart Association (BGIA 0765387B to S.M.U.).

\section{References}

1 Condliffe AM, Kitchen E, Clivers ER: Neutrophil priming: pathophysiological consequences and underlying mechanisms. Clin Sci 1998;94:461-471.

-2 El-Benna J, Dang PM-C, Gougerot-Pocidalo M-A: Priming of the neutrophil NADPH oxidase activation: role of $\mathrm{p} 47$ phox phosphorylation and NOX2 mobilization to the plasma membrane. Semin Immunopathol 2008;30: 279-289.

3 Babior BM: NADPH oxidase: an update. Blood 1999;93:1464-1476.

4 Sheppard FR, Kelher MR, Moore EE, McLaughlin NJD, Banerjee A, Silliman CG: Structural organization of the neutrophil NADPH oxidase: phosphorylation and translocation during priming and activation. J Leukoc Biol 2005;78:1025-1042.

$>5$ Borregaard N, Heiple JM, Simons ER, Clark RA: Subcellular localization of the b-cytochrome component of the human neutrophil microbicidal oxidase: translocation during activation. J Cell Biol 1983;97:52-61.

-6 Calafat J, Kuijpers TW, Janssen H, Borregaard N, Verhoeven AJ, Roos D: Evidence for small intracellular vesicles in human blood phagocytes containing cytochrome b558 and the adhesion molecule CD11b/CD18. Blood 1993; 81:3122-3129.

7 Kjeldsen L, Sengeløv H, Lollike K, Nielsen $\mathrm{MH}$, Borregaard N: Isolation and characterization of gelatinase granules from human neutrophils. Blood 1994;83:1640-1649.

$>8$ DeLeo FR, Renee J, McCormick S, Nakamura M, Apicella M, Weiss JP, Nauseef WM: Neutrophils exposed to bacterial lipopolysaccharide upregulate NADPH oxidase assembly. J Clin Invest 1998;101:455-463.

9 Ward RA, Nakamura M, McLeish KR: Priming of the neutrophil respiratory burst involves p38 mitogen-activated protein kinasedependent exocytosis of flavocytochrome b558-containing granules. J Biol Chem 2000; 275:36713-36719.

10 Uriarte SM, Rane MJ, Luerman GC, Barati MT, Ward RA, Nauseef WM, McLeish KR: Granule exocytosis contributes to priming and activation of the human neutrophil respiratory burst. J Immunol 2011;187:391-400.
-11 Dang PM-C, Stensballe A, Bousetta T, Raad H, Dewas C, Kroviarski Y, Hayem G, Jensen ON, Gougerot-Pocidalo M-A, El-Benna J: A specific p47phox-serine phosphorylated by convergent MAPKs mediates neutrophil NADPH oxidase priming at inflammatory sites. J Clin Invest 2006;116:2033-2043.

12 Boussetta T, Gougerot-Pocidalo M-A, Hayem G, Ciappelloni S, Raad H, Derkawi RA, Bournier O, Kroviarski Y, Zhou XZ, Malter JS, Lu PK, Bartegi A, Dang PM-C, El-Benna J: The prolyl isomerase Pin 1 acts as a novel molecular switch for TNF-alpha-induced priming of the NAPDH oxidase in human neutrophils. Blood 2010;116:5795-5802.

-13 McLeish KR, Knall C, Ward RA, Gerwins P, Coxon PY, Klein JB, Johnson GL: Activation of mitogen-activated protein kinase cascades during priming of human neutrophils by TNF-alpha and GM-CSF. J Leukoc Biol 1998; 64:537-545.

14 Haslett C, Guthrie LA, Kopaniak MG, Johnston RB, Henson PM: Modulation of multiple neutrophil functions by preparative methods or trace concentrations of bacterial lipopolysaccharide. Am J Pathol 1985;119:101-110.

15 Jog NR, Rane MJ, Lominadze G, Luerman GC, Ward RA, McLeish KR: The actin cytoskeleton regulates exocytosis of all neutrophil granule subsets. Am J Physiol Cell Physiol 2007;292:1690-1700.

16 Johnston RB, Keele BB, Misra HP, Lehmeyer JE, Webb LS, Baehner RL, Rajagopalan KV: The role of superoxide anion generation in phagocytic bactericidal activity. J Clin Invest 1975;55:1357-1372.

17 Omori K, Ohira T, Uchida Y, Ayilavarapu S, Batista EL, Yagi M, Iwata T, Liu H, Hasturk $\mathrm{H}$, Kantarci A, Van Dyke TE: Priming of neutrophil oxidative burst in diabetes requires preassembly of the NADPH oxidase. J Leukoc Biol 2008;84:292-301.

18 Rasband WS: ImageJ. Bethesda, US National Institutes of Health, http://imagej.nih.gov/ij/, 1997-2011.

19 Zu YL, Ai Y, Gilchrist A, Labadia ME, Sha'afi RI, Huang CK: Activation of MAP kinase-activated protein kinase 2 in human neutrophils after phorbol ester or fMLP peptide stimulation. Blood 1996;87:5287-5296.
20 Hannigan MO, Zhan L, Ai Y, Kotlyarov A, Gaestel M, Huang C-K: Abnormal migration phenotype of mitogen-activated protein $\mathrm{ki}$ nase-activated protein kinase 2-/- neutrophils in Zigmond chambers containing formyl-methionyl-leucyl-phenylalanine gradients. J Immunol 2001;167:3953-3961.

21 Coxon PY, Rane MJ, Uriarte S, Powell DW, Singh S, Butt W, Chen Q, McLeish KR: MAPK-activated protein kinase-2 participates in p38 MAPK-dependent and ERK-dependent functions in human neutrophils. Cell Signal 2003;15:993-1001.

22 McColl SR, Beauseigle D, Gilbert C, Naccache $\mathrm{PH}$ : Priming of the human neutrophil respiratory burst by granulocyte-macrophage colony-stimulating factor and tumor necrosis factor-alpha involves regulation at a post-cell surface receptor level. Enhancement of the effect of agents which directly activate $\mathrm{G}$ proteins. J Immunol 1990;145:3047-3053.

23 McLeish KR, Klein JB, Schepers T, Sonnenfeld G: Modulation of transmembrane signaling in HL-60 granulocytes by tumour necrosis factor-alpha. Biochem J 1991;279:455-460.

24 Klein JB, Scherzer JA, Harding GB, Jacobs AA, McLeish KR: TNF-alpha stimulates increased plasma membrane guanine nucleotide binding protein activity in polymorphonuclear leukocytes. J Leukoc Biol 1995;57: 500-506.

25 Fäldt J, Dahlgren C, Ridell M, Karlsson A: Priming of human neutrophils by mycobacterial lipoarabinomannans: role of granule mobilization. Microbes Infect 2001;3:1101-1109.

-26 Mansfield PJ, Hinkovska-Galcheva V, Shayman JA, Boxer LA: Granulocyte colony-stimulating factor primes NADPH oxidase in neutrophils through translocation of cytochrome b558 by gelatinase-granule release. J Lab Clin Med 2002;140:9-16.

27 Elbim C, Guichard C, Dang PM-C, Fay M, Pedruzzi E, Demur H, Pouzet C, El Benna J, Gougerot-Pocidalo M-A: Interleukin-18 primes the oxidative burst of neutrophils in response to formyl-peptides: role of cytochrome b558 translocation and $\mathrm{N}$-formyl peptide receptor endocytosis. Clin Diagn Lab Immunol 2005;12:436-446. 
28 Mollinedo F, Calafat J, Janssen H, MartínMartín B, Canchado J, Nabokina SM, Gajate C: Combinatorial SNARE complexes modulate the secretion of cytoplasmic granules in human neutrophils. J Immunol 2006;177: 2831-2841.

29 Leung YM, Kwan EP, Ng B, Kang Y, Gaisano HY: SNAREing voltage-gated $\mathrm{K}+$ and ATPsensitive $\mathrm{K}+$ channels: tuning beta-cell excitability with syntaxin-1A and other exocytotic proteins. Endocr Rev 2007;28:653-663.

30 Lominadze G, Powell DW, Luerman GC, Link AJ, Ward RA, McLeish KR: Proteomic analysis of human neutrophil granules. Mol Cell Proteomics 2005;4:1503-1521.
31 Uriarte SM, Ward RA, Powell DW, Cummins TD, Merchant ML, Luerman GC, Jog NR, McLeish KR: Comparison of the membrane proteomes from human neutrophil secretory vesicles and plasma membrane. J Immunol 2008;180:5575-5581.

32 Kjeldsen L, Sengelov H, Lollike K, Nielsen $\mathrm{MH}$, Borregaard N: Isolation and characterization of gelatinase granules from human neutrophils. Blood 1994;83:1640-1649.

33 Mansfield PJ, Hinkovska-Galcheva V, Shayman JA, Boxer LA: Granulocyte colony-stimulating factor primes NADPH oxidase in neutrophils through translocation of cytochrome b558 by gelatinase granule release. J Lab Clin Med 2002;140:9-16.

34 Anrather J, Racchumi G, Iadecola C: NF-kap$\mathrm{paB}$ regulates phagocytic NADPH oxidase by inducing the expression of gp91phox. J Biol Chem 2006;281:5657-5667.
35 Clark RA, Volpp BD, Leidal KG, Nauseef WM: Two cytosolic components of the human neutrophil respiratory burst oxidase translocate to the plasma membrane during cell activation. J Clin Invest 1990;85:714-721.

-36 El Benna J, Han J, Park J-W, Schmid E, Ulevitch RJ, Babior BM: Activation of p38 in stimulated human neutrophils: phosphorylation of the oxidase component p47phox by p38 and ERK but not by JNK. Arch Biochem Biophys 1996;334:395-400.

37 Krump E, Sangher JS, Pelech SL, Furuya W, Grinstein S: Chemotactic peptide N-formylMet-Leu-Phe activation of p38 mitogen-activated protine kinase (MAPK) and MAPK-activated protein kinase-2 in human neutrophils. J Biol Chem 1997;272:937-944. 